\title{
A Critical Appraisal of the Traditional Leadership Styles in Igboland, South-Eastern Nigeria
}

\author{
Akakuru Ojiugo $^{1}$.C, Nwokedi Chidi I. ${ }^{2}$, and Okoli Ezinne ${ }^{3}$ \\ Department of Social Studies, Alvan Ikoku Federal College of Education, Owerri, Imo State, Nigeria.
}

\begin{abstract}
Igbo traditional rulers as embodiment of custom an important aspect of their ceremonial role are highly ambiguous. Much of what might be regarded as a genuine local tradition in Igbo society is connected with traditional religion its shrines, practices and rituals. However, already many warrant chiefs of the early colonial period supported Christianity, even if the alliance with the missions remained shaky. The Igbos life did not just start with colonization rather before the advent of the Europeans, Igbos already had a philosophy, established structure of government which was democratic, education and technology when they say "Igwe bu ike". (Relations are strength), Agwo otu onye huru bu Eke, (snake seen by one man is python) this means that the democratic spirit in Igbos check any possible excesses arising from unnecessary seniority, status and achievement. This work ex-rays the styles or patterns of administration of the traditional leaders in Igbo land especially since early 1970s. It realized that traditional leaders are not highly recognized in the Igbo land, unlike the traditional leaders of some other tribes like Yoruba, Edo, Hausa, etc .The study equally looked at the symbolism employed by them and also their characters, the Igbo land traditional leaders are more of civil servants and have their private businesses.
\end{abstract}

Keywords: Igbo land, Leadership Style, Tradition, Traditional Rulers, Warrant Chiefs.

\section{Introduction}

The Igbos are traditionally predominantly farmers and traders. The area traditionally occupied by the Igbos has been defined as the Igbos culture area, where they live in groups of patrilineages (Umunna) which are hierarchically arranged. Patrilineage of various levels and origin form villages, and groups of villages form towns (Obodo). Recent studies show that these towns have been peopled by nine major migrations, beginning before AD 900 and continuing into the beginning of this century Onwuejeogwu (1975:178).

The Igbos are grouped into five sub-cultures, the southern Igbos centered around Owerri - Ngwa have the distinctive cultural features of the absence of elaborate title and mmuo societies and the presence of Mbari Temples. The Northern Igbos are centered around Nnewi, Nri, Awka, Nsukka. Their distinguish features are the Ozo title and an elaborate ancestor temple system, Ohu. The distinctive features of the eastern Igbos comprised an elaborate age - grade system and inheritance through the male and female lines. Among them are the Aro who are patrilineally organized. The North-Eastern Igbos has a distinctive house, title system and an ancestor cult associated with graves. The West - Igbo are characterized by having either a centralized kingship authority superimposed on hierarchies of patrilineages as in Agbor, Aboh, Oguta, Okwashiugwu or a gerontocratic centralized system as in Ibusa and Okpanam.

Apart from these cultural diversities, the Igbos share a common basic culture in their language which has a cluster of dialects that are mutually intelligible, they share a common political system based on decentralization of power and delegation of authority exercised by the holder of the staff of authority, ofo, this system is epitomized in the hierarchy of lineages called Umunna. Finally, certain distinctive traits bind the Igbos into a cultural unit, among them are their folklore, oral literature, their mmuo, traditional games and most importantly their leadership styles (Onwuejeogwu, 1970:6). These study emphases on the study of the styles of leadership that exists in the Igbos land from pre-colonial era till post colonial era.

\section{Leadership In The Pre- Colonial Era}

The Igbos life did not just start with colonization rather before the advent of the Europeans, Igbos already had a philosophy, established structure of government which was democratic, education and technology when they say "Igwe bu ike". (Relations are strength), Agwo otu onye huru bu Eke, (snake seen by one man is python) this means that the democratic spirit in Igbos check any possible excesses arising from unnecessary seniority, status and achievement. This is further strengthened by the Igbos principle of equality and equivalence which rightly brought out in the saying "egbe bere Ugobere, nke si ibe ya ebela nku kwa ya" which means 'live and let live'. This is fundamental in Igbo thought pattern. Ndi Igbo don't worship people rather; they have sanctions against rude people. They accord respect to anyone the respect is due for. As they respect their elders, they resent oppression and authoritarianism. 
The original Igbos understanding of leadership which the colonialists succeeded in destabilizing and erasing is that every Igbo community strives to elect "collective" leaders who function as partners and colleagues of the other members are themselves called to do something to function actively as partners and colleagues. Membership and leadership are organic whole, they have influence on each other. Leadership on the other hand resides in the person the members elect and it resides also in the members (Tell Magazine 1998). That is why it is believed in Igbo Land that "Igbo enwe Eze".

\section{Historical Perspective Of Igbo Chieftaincy Leadership}

Most classical social anthropological and historical accounts of Igbo society have described it as prototypically "stateless" a cephalous or segmentary (Meek 1937, Green 1947, et al). Uchendu (1965) sees it as consisting of autonomous villages and village groups (Obodo, town) rulled by diffused authority without formalized, permanent, or hereditary leadership positions. Uchendu (1965) described the prototypical Igbo traditional political organization as an exercise in direct democracy on the village level, with a representative assembly, on the level of the village group. Some Igbos communities, especially trading cities along the Niger like Onisha and Oguta and the holy city of Nri had elaborated chieftaincy institutions in pre-colonial times. Especially the case of Nri has influenced both academic and popular imagination, because the stirring archaeological findings at Igbo-ukwu seem to suggest to some authors the existence of a one thousand year old tradition of Nri sacral kingship and hegemony over large parts of Igbo land.

This theory is welcome in current popular and political debates about chieftaincy in Igbo land, as it seems to be able to improve the traditional character of contemporary Igbo traditional Rulers' title. Nonetheless, even in current debates in Nigeria, most people continue to view Igbo's society as being traditionally based on democratic principles' (Aguwa 1993:20) as expressed in the common proverb Igbo enwe Eze; the Igbos have no king.

However, democratic, inner structures of pre-colonial Igbos communities were far from egalitarian. Igbo society had its slaves (ohu) and cult-slaves' (Osu) on the other hand, and it has leaders. Depending on the sub-cultural area of Igbo land we are talking about, there were lineage headships, influential age groups, and powerful titled and secret societies. Some individuals were carrying the title Eze or Obi, indicating a special degree of influence and power though not independent of the person and especially, the wealth it could mobilize. In leadership positions, a common feature is their high degree of local diversity, in two ways; first, the rules by which an individual obtained a position differed from place to place. Second, while certain Igbo communities (especially Nri and Arochukwu) exerted a certain wide-range commercial or ritual influence, the leaders even of these communities did not exert direct power outside of their own community.

\section{Colonial Chieftaincy Leadership}

The introduction of the so called "warrant chiefs" was introduced in Igbos land by the British colony. The British introduced what they called 'Native courts' and equally installed chiefs by warrant (hence the name) who controlled them. Usually or often, these warrant chiefs were installed arbitrarily. In some cases, personalities were installed had been local leaders before, but were often, it was usually an accidental affair. In some cases, the villagers forwarded people of little standing in the community to the British. On the periphery of Igbo land, sometimes people of external origin were also installed. The warrant chiefs of Igbo land were installed without much recourse to local traditions of hierarchy and status, without taking into accounts the details of pre-colonial local political structures. Although, the reasons for this was that the British knew very little about the pre-colonial organization of the communities which they had brought under control. The British believed that Africans had to be governed by chiefs, some how - it was a very crude vision of indirect rule, but still believed to constitute indirect rule, at least in its early years (Afigbo, 1967).

These warrant chiefs held power and used it for their own gain. Their main source of power was the control of Native courts and of labour (Ofonagoro, 1982). By the 1920s, the warrant chief institution had, in many places become synonymous with greed and corruption, and the British administrative officers were increasingly aware of this. But the system did not break down before the famous 1929 women's war which took place in large areas of south Igbo land and of the Ibibio speaking - areas future southeast. Thousands of women attacked native courts and besieged warrant chiefs (sitting on a man, Ivan Allen 1972). The women's war made unmistakably clear the little legitimacy of warrant chief rule. The reason behind the riots were more multifaceted, firstly that after the mens' direct tax in 1928, women would also be taxed again, the fall in palm produce prices due to the world wide recession aroused much anger and was attributed to manipulations by the European trading firms, the promises of which were also attacked in several places.

Based on these reports and many others reports, in 1930s, new local Native Authority councils and courts composed of elders and other members of the local elite were created (Ishi ani). They were given the responsibility of reassembling traditional structures of local government more closely. The councils then 
received much local critics, both for what was seen as their non-traditional character and again, because of their corrupt practices (Afigbo 1981:322).

\section{Leadership Roles Of Igbo Land Traditional Rulers}

Most functions of Igbo traditional rulers lie within the autonomous community. For example, the role of the impartial father involves peace making function within the community and in conflicts with neighbours. A traditional ruler should also promote local development, and achievements in this aspect play a major role in most documents where traditional rulers present themselves publicly. A traditional ruler should organize local consensus, by consultation of his cabinets a council of local presentations and elders.

The traditional rulers act as instruments of state control on the local level in the South-eastern Nigeria. Usually, they are automatic members of the customary courts which were reconstituted since late 1970s because customary courts were abolished by the post civil war, Asika Administration (Awa 1992:47).

They should not only assist in the collection of taxes but co-operate with the Local Government Council. In Anambra State, traditional rulers who successfully manage the tax collection effort, receive a commission on the proceeds (Anene \& Akus 1985:2-3). Governments in the South-eastern zones like to see traditional rulers as transmission belts for promoting their policies for examples the "war Against Indiscipline' of the Buhari year, into the local sphere (ibid. 3).

They have to be known as men of considerable own means, as government 'stipends' have not been regular in all the states in South-eastern zone. It is only few that are well-connected traditional rulers seem to receive government funds on a large scale. Many African traditional rulers receive regular income from land rents but it is not usually the some in Igbo land, same receive while majority of them do not. Their major source of income is realized during the conferment of Honorary Chieftaincy titles. This makes majority of our people perceive this practice as a process of 'bastardization' of chieftaincy titles that seem to have become easily purchasable.

\section{Post Colonial Traditional Leadership Styles In Igbo Land.}

The recognition of chieftaincy institutions officially returned in the course of the Nigeria-wide local government reform of 1976, this created structures which still exist till today. This reform wanted to bring government closer to the people and to strengthen the role of the local level as a third tier of government, besides the Federal and state levels.

Traditional rulers, as the Udoji public service Review commission had put in 1974 were believed to be important, even in the context of a development - oriented society, to act as the impartial fathers of their communities and embodiment of local custom. This policy was applied not only in the North and South-west, with their strong traditions of chieftaincy, but in the south-east a well.

\section{Government Policies And Legal Aspects In Leadership}

The establishment of autonomous communities and the installation of traditional rulers originated in recommendations made by a committee consisting of academic and civil servants in 1976 (Anambra State of Nigeria 1976), its chairman was the most prominent historian of Igbo society, traditional rulers proposed by autonomous communities, according to the law government should refrain from intervention into the details of the selection process, but it reserves the right of deposing a traditional ruler, for example, for the interest of peace, order and good government. It is only the government recognized traditional rulers are legally entitled to carry the titles of Eze and Igwe, they may confer honorary titles to other traditional rulers as well as considerable parts of the political class have been manipulated into supporting the Democracy regimes.

Igbo traditional rulers do not belong to a separate aristocratic class, as traditional rulers in some other areas in Nigeria do. Traditional ruler's role in developmental projects and their educational careers are given in much detail - only 3 cases mention in formal education. Nearly one-third of Traditional rulers claim some tradition of office in their family background, but this does not necessarily mean that they inherited their position. However, the claims may indicate certain familiar continuities in local positions of power existing for at least parts of the $20^{\text {th }}$ century, in some cases directly starting from the warrant chiefs of the first decades of the colonial period. In this more recent sense, Igbo's chieftaincy traditions might on a closer look, be stronger than often assumed.

Traditional rulers provide examples for both types of legitimacy on which the position of traditional rulers may be based either on descent and tradition or on popular consent; Eze (Dr) Onu Egwunwoke, Oha I of Ihitaoha Uratta, Owerri, Imo (Offonry 1993) and Eze Patrick I. Acholonu, Igwe 1 of Orlu, Imo (Okemezie 1990) are sons of colonial warrant Chiefs. They received a good education and seem to have been able to take over the titles from their fathers without serious challenge they claim a hereditary character of their titles as is otherwise common only among communities like Onisha, Nnewi in Anambra State. Igbos used to have chieftaincy institutions in the pre-colonial period. The cases of Nathanial Ogbonna, Obi I of Nkpologwu, 
Anambra, Eze Justus O Ugochukwu Eshi II of Nkwerre, Imo (Ozurumba/Uzoechi 1990) Igwe Edward Nnaji, Odezuligbos 11 of Nike, Enugu (Anene et al 1985) and Lawrence N. Ukah, Ohaire I of Mgbowo, Enugu. Whereas Ugochukwu is a son of a lower colonial chief and went to school, Ogbonna, Nnaji and Ukah do not claim any royal background. The latter two have little education. All these traditional rulers acknowledge their communities active support, especially by their respective town, town unions, in their gaining the title.

Igbo traditional rulers as embodiment of custom an important aspect of their ceremonial role is highly ambiguous. Much of what might be regarded as a genuine local tradition in Igbo society is connected with traditional religion its shrines, practices and rituals. However, already many warrant chiefs of the early colonial period supported Christianity, even if the alliance with the missions remained shaky (Omenka 1993:248).

Among contemporary Igbos traditional rulers, there is hardly anybody not professing to be a Christian. However, Igbo traditional rulers regard themselves as ceremonial overseers and keepers of culture as represented by specific local festivals, masquerades and other customs, though without too much public reference to the religious meaning of these practices.

Igbo traditional rulers present themselves to the public with symbols borrowed from various sources. For example, Chidiobi (1996:56) identified that Nike Traditional Ruler, Edward Nnaji's chamber in his multimillion naira ultra-, modern palace contains an assortment of throne, tables and chairs, the decoration of which reminds of $18^{\text {th }}$ century French absolutist court interiors. At the same vain he surrounds himself artificial elephant tusks, a symbol of power in pre-colonial Igbo land as well as in Benin, yet Christian imagery is equally seen in the same palace. They therefore appropriate local and alien symbols of power by means of bricolage, and thus prove their potency as representatives of a culture which is invariably far from purely locally - based tradition.

\section{Criticisms Of Igbo Land Traditional Leaders}

It is unfortunate to hear that Igbo traditional rulers remain contentious, among intellectuals as well as among the general populace. For intellectuals, traditional rulers are frequently objects of ridicule and harsh critique, a typical example is the exorbitant money they charge during the conferment of honorary chieftaincy titles. They present themselves to the public with symbols borrowed from various sources. Therefore, Chima Achebe arguably the most famous southeastern Nigeria writer, mocked at Igbo traditional rulers as 'Traders' in their stall by day and monarchs at night city dwellers five days a week and traditional village rulers on Saturdays and Sundays. They adopt "traditional" robes from every land, including regalia of the Lord Mayor of London (Achebe 1983:48). Arthur Nwankwo, a prominent pro-democracy activist, recently criticized the wanton prostitution of Igbo land, cultural and political heritage by new apostles of pseudo - traditionalism, Nwankwo (1996:11) which in effect, helped to stabilize military rule.

Traditional rulers are widely perceived as belonging to elite which often enough is corrupt and does not fulfill the functions expected from it. This explains the breaking out of violence in public against the traditional rulers recent times. It is worthy to note that in September 1996 riots erupted in Owerri after several cases of ritual murder had become public, the outstanding' palace of Eze Onu Egwunwoke, Chairman of Imo state council of Ndi Eze and a close ally of the ruling military junta was among the many building attacked in town. Similarly, in July 1997, traders rated in Aba after the police had turned out unable to protect them against a series of armed robberies, and burnt the palace of Eze Iseac, Ayonu Ikonne, Enyi I of Aba, who is a member of Abia State council of Ndi Eze.

\section{Conclusion}

This work has ex-rayed the styles or partterns of administration of the traditional leaders in Igbo land especially since early 1970s. It realized that traditional leaders are not highly recognized in the Igbos land, unlike the traditional leaders of some other tribes like Yoruba, Edo, Hausa, etc. But Igbo land traditional leaders can be regarded as embodiment of local custom in administratively defined autonomous communities, they act as patrons and mediators within the community and serve as transmission belt for government policies into a local sphere. Although among them are numerous wealthy businessmen with excellent official connections, but majority of them claim that they are just successful farmers.

Within them are the descendants of colonial warrant chiefs claiming a hereditary character for their position, but there are also numerous traditional leaders whose selection was based on support by their town union members, and who seem to view their office in more humble terms, as an honour given by the community.

The study equally looked at the symbolism employed by them and also their characters, the Igbo land traditional leaders are more of civil servants and have their private businesses. They received formal education and are adherents of the Christian religion. They combine Democratic leadership style with autocratic, style. They use imbibed local and foreign symbols. Their leadership style has in most cases no traditional roots. 


\section{References}

[1] Aborisade, Oladimeji (ed) (1985). "Local Government and the traditional rulers in Nigerians. Ile-lfe, University Press.

[2] Achebe Chima (1983). "The trouble with Nigeria". Enugu fourth Dimension Publishers (reprint 1985).

[3] Afigbo, A.E. (1972). The warrant chiefs: indirect rule in South eastern Nigeria (1891 - 1929) London: Longman.

[4] Afigbo, A.E. (1981). Roles of Sandi studies in Igbos history and culture”. Ibadan, University Press.

[5] Afigbo, A.E. (1997). "Igbos Titles of Honour. A typology Keynote Address, International Workshop on Traditional titles and Honours in the Igbos culture Area of Nigeria. Institute of African studies, University of Nigeria Nsukka, February 20-21 1997.

[6] Agunwa, C.U. (1993). Theoretic Traditions and the Igbos experience” In Anyanou/Agunwa (1993).

[7] Anambra State of Nigeria (1976). Government white paper on the report of the committee on Chieftaincy matters' Enugu government printer.

[8] Anene,.V.C. et al (1985). “Anambra State Government and recognized traditional rulers. Comments, pictorial and biographical notes. Onitsha press.

[9] Awa, Eme.O (1992). The transformation of rural society a study of rural development in the Eastern states of Nigeria (1970:76).

[10] Axel, Harmeit - Sieves: Igbo Traditional Rulers Chieftaincy and the state in south eastern Nigeria Afrika spectrum 33 (1998) 1:5779.

[11] Chidobi, R. (1996). A legend of our time. The biography of His royal Highness Igwe Edward. A. Nnaji, Enugu Jemezie.

[12] Nnamani, J.O. (1985). Nike chieftaincy 1919-1985". Enugu government printer.

[13] Offonry, H.K. (1993). Royal Eagles. Eze Onuegbou nwoke" Owerri, New African publishers.

[14] Okemezie, Okems (1990). "More than five decades on reign. Aba, Goodoms.

[15] Omenka, N.I. (1993). The Church and traditional leadership in Igbosland" in Anyanwu (Agunwa 1993) 241 - 253.

[16] Uchendu, V.C. (1965). The Igbos of South east Nigeria. "New York, Rinehart \& Winston.

[17] Van Allen, Judith (1972). Sitting on a Man; colonialism and the lost political institutions of Igbos Women”. Canadian Journal of African Studies (1972). 